ISSN 1816-6075 (Print), 1818-0523 (Online)

Journal of System and Management Sciences

Vol. 11(2021) No. 2, pp. 77-105

DOI:10.33168/JSMS.2021.0206

\title{
City Logistics Analysis of Urban Areas: An Analytic Hierarchy Process Based Study
}

\author{
Dávid Lajos Sárdi ${ }^{1}$ and Krisztián Bóna ${ }^{1}$ \\ ${ }^{1}$ Budapest University of Technology and Economics, Department of Material \\ Handling and Logistics Systems, Hungary \\ david.sardi@logisztika.bme.hu (corresponding author) krisztian.bona@logisztika.bme.hu
}

\begin{abstract}
Nowadays, the urban freight traffic is a very important research area because of its significant effect on the urban sustainability, and the last period with the COVID-19 pandemic highlighted its importance again, with the increasing of share of the number of home deliveries in the crowded cities. In this field, we should focus on the problems of the logistics systems of the so-called urban concentrated sets of delivery locations (e.g. shopping malls or markets), as in their case, it is needed to serve lots of stores in a very small area. Based on the results of former research projects, it can be said, that it could be really important to develop such a ranking model, which could rank the current city logistics state and the future city logistics development potentials of these concentrated sets of delivery locations and other urban zones with single delivery locations at the same time. In this paper, we are going to present an Analytic Hierarchy Process based multicriterial ranking model, which makes it possible to rank urban areas in a twodimensional system, where the first dimension is the current city logistics state, and the second one is the future development potential. The main purpose of this ranking is to mark urban zones in future city logistics projects those, which could be well developed, and it is worthwhile to develop them. We are going to write about our former related research results and about the formalization of the AHPbased model. As we work and live in Budapest, our model was tested on this city, for first, on 4 shopping malls. We are going to present the results of the tests, the first results of the sensitivity analysis, and the next steps of the research. This paper is a revised and expanded version of a paper entitled "AHP-based multicriterial ranking model for the city logistics analysis of urban areas" presented online at the 10th International Conference on Logistics, Informatics and Service Sciences (LISS2020), on July 27, 2020.
\end{abstract}

Keywords: Logistics, city logistics, urban logistics, AHP, ranking model, simulation, shopping mall. 


\section{Introduction}

In the City Logistics Research Group of the Department of Material Handling and Logistics Systems at the BME (Budapest University of Technology and Economics), our research project was started in 2015 to examine the city logistics systems of the so-called urban concentrated sets of delivery locations (BME-ALRT, 2020). For this research, the urban delivery locations can be assigned to two groups (as it can be seen on Figure 1): there are single delivery locations and concentrated sets of delivery locations (referring to CSDL; these are basically, groups of single delivery locations) (Bóna \& Sárdi, 2018), they are in the focus of our research nowadays because of their significant consolidation potentials. As it can be seen on Figure 1, in case of the examined CSDLs two type of concentration can be defined: concentration with open and with closed infrastructure. In case of open infrastructure, the set is defined by an open area, so roads and squares can mark the borders of the set, like in case of a shopping area/street or an open market. In case of closed infrastructure, the set is defined by a closed area, which means in this case a building, like in case of shopping malls, hypermarkets or duty-free areas of airports (Bóna \& Sárdi, 2018). We also defined special sets in case of closed infrastructure, as we recognized, that for example the logistics properties of universities or hotels are really like the previously examined concentrated sets of delivery locations.

\section{Delivery locations in the examined urban area}

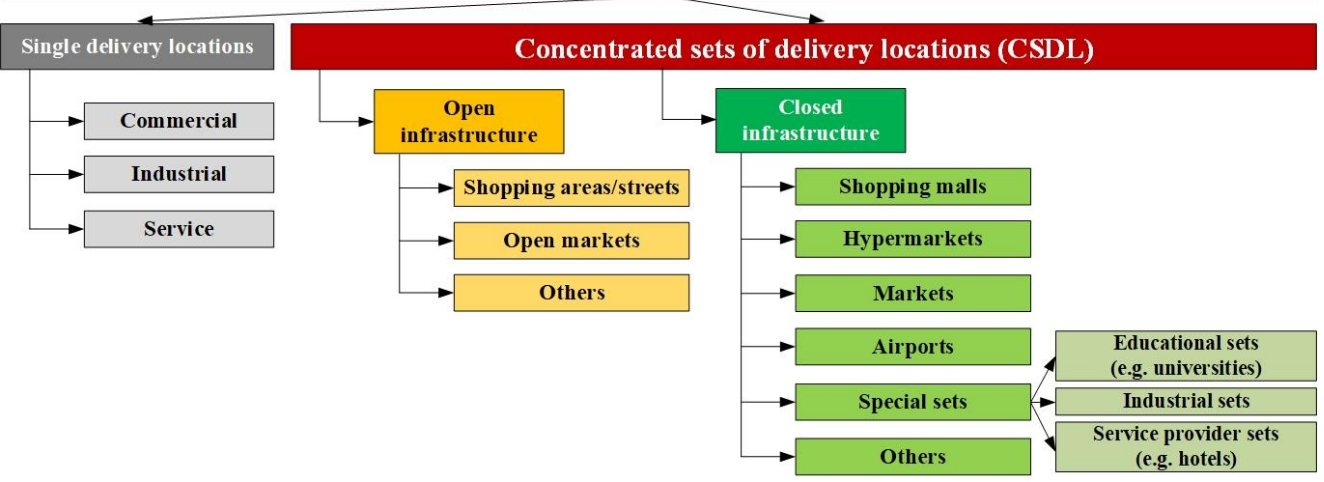

Fig. 1: Groups of the examined delivery locations (extended with special CSDLs)

Despite the fact that the CSDLs have a significant goods traffic with significant development potentials based on former city logistics projects, they are not in the focus of logistics researches and at the planning phase of the CSDLs the logistics aspects (such as sizing, modelling and optimization) are not as important as the customer aspects (Bóna \& Sárdi, 2019), mostly only some of their subsystems are examined (e.g. only the loading areas of shopping malls). As a result of this, the City Logistics Research Group started to examine these CSDLs, we collected data about 
their city logistics characteristics, developed some new system concepts and developed mathematical, simulation and topological models (Bóna \& Sárdi, 2019).

In this paper, such a multicriterial ranking model will be presented, which can rank the current city logistics state and the future city logistics development potentials of urban zones at the same time, but not only for these CSDLs, but for other urban zones as well, which contain single delivery locations (and even smaller CSDLs too). In this ranking model, we would like to examine the viewpoints of the current city logistics systems, the regulations, the use of different transportation modes and combined logistics solutions, the degree of concentration, and every relevant performance, emission and cost parameters both for the current system and for the possible future solution (green, consolidated and gateway-concept-based new city logistics solutions) too. As an example, on Figure 2 an examined urban area can be seen.

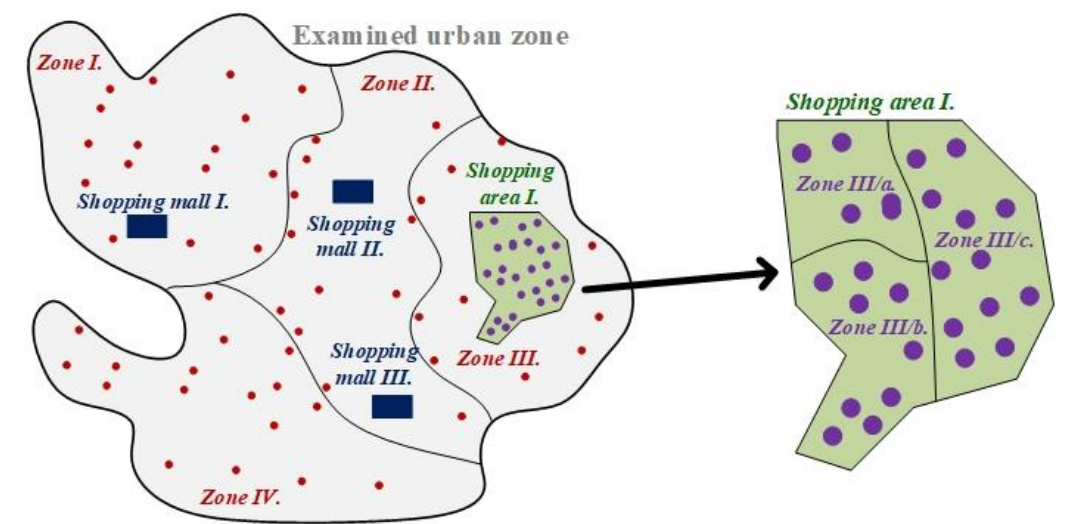

Fig. 2: Example of an examined urban zone with 10 zones (Bóna \& Sárdi, 2019)

The example above contains 10 zones: 4 simple urban zones with single delivery locations, 3 shopping malls and 1 shopping area (which can be divided to 3 subzones, as it has a bigger area with significant number of delivery locations). For this area, the currently examined ranking model will be able to decide, which of the 10 zones is currently in the best city logistics state and which one of them could be the best developed in the future. Later, on Figure 4, the same zones are examined.

\section{Multicriterial ranking models in city logistics}

As a first step of the research, a literature research was performed, where we were looking for the former ranking models and other multicriterial models in city logistics and in other logistics fields. In this phase, 3 scientific databases were used: ScienceDirect, ResearchGate, and Google Scholar.

We would like to highlight 3 of the examined ranking models. The first of them deals with bigger supply chain networks and its main purpose is to rank logistics centers with different functions and from different layers of the network (Antún \& 
Alarcón, 2014). A similar model could be implemented for the junctions and even for the zones of a city logistics network. One of the two other raking models ranks city logistics projects (Patier \& Browne, 2010), and the other one examines the operation suitability of electromobility concepts for last mile delivery tasks (Teoh et. al., 2016), so they have similar aspects as we needed for the evaluation of the city logistics development potentials. In case of some other publications, different multicriterial models were used for the evaluation of city logistics developments (Awasthi \& Chauhan, 2011) (Tadić et. al., 2017) and for the selection of the best concepts (Tadić et. al., 2014). Above these, for several different purposes can the multicriterial methods be used in city logistics: for the evaluation of the performance of city logistics terminals (Gogas et. al., 2017), for urban sustainability aspects (Kara et. al., 2019), for regulation evaluation (Janjevic et. al., 2019), for vehicle selection (Wątróbski et. al., 2017) and for urban facility location problem solution as well (Zhao et. al., 2018) (Awasthi et. al., 2010) (Uysalh \& Kemal, 2014), but our two purposes (to examine the current state and the development potentials in the same time) were not examined together in these researches.

In the literature research, we were also looking for the possible multicriterial models, they can be used for the current research. For this, sum 48 papers, books and thesis about city logistics projects (and from other logistics fields as well) were examined, and the results can be seen on Figure 3 (some of the researches used more than 1 multicriterial methods). In the others category, we added the researches, which used MAMCE, DEA, EDAS, ELECTRE, Fuzzy BOCR-GRA, MCE, PCA, MCA or neural network-based solution.

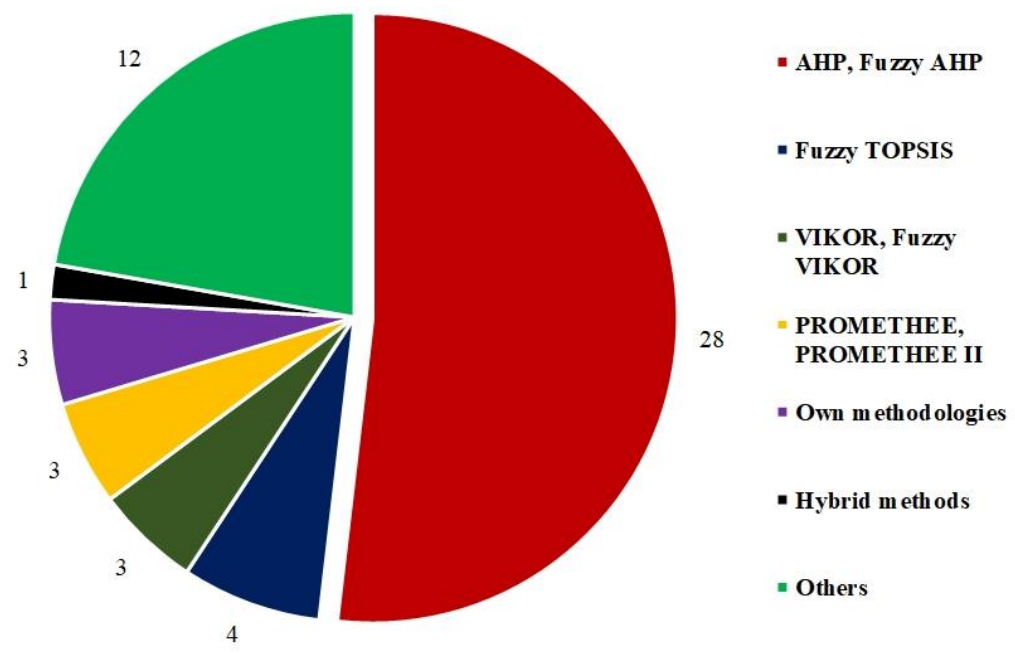

Fig. 3: Multicriterial models in the examined logistics researches (Bóna \& Sárdi, 2019)

The main results of the literature research can be seen below: 
- there are several different multicriterial ranking methods in the field of city logistics (as it can be seen on the figure above), but none of them had the same purposes as the current research, so the ranking model, which examines the current city logistics state and the future development potentials in the same time, will be an absolutely new application;

- the AHP (Analytic Hierarchy Process) method (Saaty, 1987) and its subversions have significantly more documented application in city logistics and in other logistics field (47\% of the used methods in city logistics and 52\% in every logistics fields is AHP or fuzzy AHP), than any other method, so we can conclude that AHP is an appropriate method for the evaluation of logistics systems, this method was used in the currently examined research.

\section{Previous research results}

In this chapter, we would like to highlight our main research results (which research project focused on concentrated sets of delivery locations), as they are going to be very important input data in the application of the AHP-based ranking model in the current paper and in the future research steps as well.

\subsection{Data collection about CSDLs}

In the first phase of the currently examined research, we had to collect data about the stores of the examined CSDLs (from Budapest; we focused on this city as a first step), as there was no available (and enough detailed) data about the city logistics characteristics of them or about single delivery locations of any other urban zone. We can say that the situation is similar in every other city, so always the available data is the most important question in these projects. Between 2015 (September) and 2020 (August), 6 CSDLs from Budapest were examined (4 shopping malls, 1 market and 1 shopping area) and sum 630 stores of them (we interviewed sum 1,222 stores, so the response rate was $51.55 \%$ ). 24 people participated in the data collection, from the City Logistics Research Group, several logistics engineer BSc and MSc students, and some transportation engineer BSc students. The data collection was performed by use of our own methodology, which contains a complex questionnaire with 31 questions in case of shopping malls and markets, and 32 in case of shopping areas about all important logistics parameters (e.g. general properties, delivery vehicles, logistics units, delivery times, inverse logistics, IT systems, e-commerce) (Mészáros et. al., 2016) (Mészáros et. al., 2017). The number of examined stores and the willingness of the stores to participate in our research can be seen in the list below:

- $\quad 1^{\text {st }}$ shopping mall (middle-sized, in the center of Budapest; 2016): 105 of 140 interviewed stores answered (75\%);

- $\quad 2^{\text {nd }}$ shopping mall (small-sized, in the center of Budapest; 2017): 51 of 75 interviewed stores answered (68\%); 
- $\quad 3^{\text {rd }}$ shopping mall (large-sized, in the center of Budapest; 2017): 171 of 308 interviewed stores answered $(55.5 \%)$;

- "Váci utca" shopping area (biggest shopping area in the center of Budapest, 2017-18): 163 of 422 interviewed stores answered (38.6\%);

- $\quad 4^{\text {th }}$ shopping mall (middle-sized, in an outer district of Budapest; 2019; examined by a shortened version of the questionnaire for a project which was focused on the possible use of the metro-network for city logistics purposes): 50 of 120 interviewed stores answered (41.7\%);

- $1^{\text {st }}$ market with closed infrastructure (large-sized, in the center of Budapest; 2020): 90 of 157 interviewed stores answered (57.3\%).

Based on the results of the data collection (for 540 stores of 4 shopping malls and 1 shopping area, as the results related to the examined market are not analysed yet), in the current city logistics system of the CSDLs, the deliveries are not synchronized with each other, and this means that the big amount of goods is delivered in several parts, in smaller vehicles (mostly in vans or in the passenger cars of the workers) with low utilization. Based on the data collection, there is daily average 0.98 delivery per store (so yearly average 357 delivery per store). In these deliveries, daily approximately sum 3,900 pcs of boxes, 250 pallet unit loads, 3,000 clothes hanger units and 1,300 other units are handled in the examined stores. This means daily more, than 80 tons of goods, so yearly sum 30,000 tons of goods, only for the responder stores from 5 CSDL from Budapest, where only in the CSDLs more, than 4,000 stores can be found, and the sum number of retailers in the city was nearly 30,000 before the pandemic. As it can be seen, huge volume of goods is handled, and the delivery processes can be improved by organization (so-called gateway-based) solutions (Sárdi \& Bóna, 2019/c) (Sárdi \& Bóna, 2019/b) (Sárdi \& Bóna, 2017).

The results of the data collection clearly showed us, that the problems, we expected are real in the examined city logistics system, and we also got some data about the willingness of the storeowners to participate in new city logistics solutions. For them not only the financial aspects, but also the green aspects are important, based on their answers. In the next chapter, we would like to write about the simulation modelling phase of our project, where the data collection phase provided the input data for this research.

\subsection{Simulation models of the logistics system of CSDLs}

Next step of the research was to model the current city logistics system of the CSDLs and some new concepts as well (Bóna \& Sárdi, 2019). First, we developed the mathematical model of the current and the new, consolidation-based system (Bóna \& Sárdi, 2018) (Sárdi \& Bóna, 2019/c) (Sárdi \& Bóna, 2019/b). Next, we developed the mesoscopic, MS Excel based simulation model of the current and the new system, first between the city borders and the logistics areas of the CSDLs (Sárdi \& Bóna, 
2017) and then for the whole logistics process between the suppliers and the customers of the CSDLs (Sárdi \& Bóna, 2019/c) (Sárdi \& Bóna, 2019/b). Additionally, we developed the mathematical model of the cost structure (Bóna et. al., 2018), the topological model of the CSDLs with open infrastructure (Sárdi \& Bóna, 2019/b), and the geometrical model based macroscopic simulation model of a special cargo bike city logistics system (Sárdi \& Bóna, 2018) (Sárdi \& Bóna, 2019/a). By use of the mesoscopic level MS Excel based simulation model (developed by us), we received lots of interesting results, they showed us, that it is worth to examine this special city logistics field. In the simulation, 217 stores of 4 shopping malls were examined, as they provided the best, most detailed data in the questionnaires; the currently examined AHP-based ranking model will be tested for these malls as well.

Based on the simulation results, in the current logistics system in one month, 1,759 tons of goods are handled (st. dev. 24.2 t), which generates monthly 3,990 delivery transactions for the 217 examined stores (st. dev. 17,6) with additional empties handling as well. For these deliveries, the sum monthly mileage is $780,022 \mathrm{~km}$, which generates for example $137.4 \mathrm{t} / \mathrm{month} \mathrm{CO}_{2}$-emission. To compare with the current system, two new city logistics concepts were examined, where a consolidation center and cross docks were placed to the system, and the consolidated deliveries were handled by bigger road vehicles or by cargo trams (Bóna \& Sárdi, 2018) (Bóna \& Sárdi, 2019) (Sárdi \& Bóna, 2019/b). In these concepts, based on the simulation the modelled goods amount was 1,781 tons between the suppliers and the consolidation center (st. dev. $88.7 \mathrm{t}$ ), and 1,750 tons between the center and the examined shopping malls (st. dev. $51.7 \mathrm{t}$ ); the difference comes from the independent experiments, from the different logistics processes and from the independent random number generation. This amount generated between the suppliers and the center monthly 1,507 delivery transactions (st. dev. 14.5); and additionally, between the center and the malls by use of road vehicles 401 consolidated transactions (st. dev. 11), and by use of cargo trams 174 consolidated transactions (st. dev. 3.8). To handle these amounts, the sum mileage in case of road vehicles was $376,736 \mathrm{~km}$ (which means $51,7 \%$ reduction), and in case of cargo trams it was reduced to $371,963 \mathrm{~km}(52,3 \%)$. In the first case, the sum $\mathrm{CO}_{2}$-emission is reduced to $55.5 \mathrm{t}$, in case of cargo trams the direct emissions can be reduced even more.

We also evaluated the logistics costs in both cases, by use of our simulation model (Sárdi \& Bóna, 2019/b) (Bóna et. al., 2018). Based on the simulation runs, in the current system for 217 stores of 4 shopping malls, the sum monthly sum logistics cost is $450,666 €$ (st. dev. $14,664 €$ ), and the delivery costs have the biggest share of this, with monthly sum $359,747 €$. In the new system, this amount can be reduced by $38,2 \%$ in case of road vehicles, and by $44,3 \%$ in case of trams. This means in the first case sum $270,556 €$ monthly logistics cost (st. dev. 9,139 €) and 250,839 $€$ in the second case (st. dev. 7,518 €) (Sárdi \& Bóna, 2019/b). This means, that in the new logistics system not only the performances and the emissions can be reduced, but also the costs 
of the daily operation. Of course, the examination of the investment costs is a very important aspect in this project. These all data will be able to help a lot for the evaluation of the current city logistics state of the examined urban zones and the change of these parameters will provide very important input for the evaluation of the future city logistics development potentials.

Based on the previous results, now we can examine the expected investment costs of developing the cross docks of shopping malls or shopping areas (Bóna et. al., 2019). The examination of loading areas of shopping areas is currently ongoing, and we defined the consolidation center planning as basic warehouse planning tasks. It is also important to highlight here, that the MS Excel-based simulation model became really slow because of the huge amount of data, so we started to search for new simulation solutions. A mesoscopic level pilot model in AnyLogic was already developed both for the current system and the new, consolidation-based solution, and the development of microscopic level, Python-based pilot model is currently ongoing too, this one of the most important tasks in this research now (Sárdi \& Bóna, 2020/b).

\section{Development of the AHP-based ranking model}

How to handle the two different purposes (to examine the current city logistics state and the future city logistics development potentials in the same time), this was the first important question in the development phase of the ranking model. It was expected, that here will be some criteria, they will affect both (e.g. the current state of the infrastructure or the current regulations, as they can give the basics of the future developments as well) and they can have different weights in the cases, we decided to use a two-dimensional solution, where two AHP-based models are used in the same time. One of them will examine the current state and the other one will examine the future development potentials. So, our ranking model will be able to handle both purpose in the same time, and its result will show us, how developed is the examined urban zone currently and how can it be developed in the future.

The expected results of the ranking can be seen on Figure 4 (with the same zones, as on Figure 2 earlier), where the points show the ranking values of the zones, and the zones are assigned to two groups. On this figure (and later, in the tests), the intervals for the current state levels and for the future development potential levels are the same: $33.33 \%$ and $66.67 \%$. Some typical expected results of the evaluation can be seen on this figure well:

- there are zones, they are not well-developed, but they can be developed well in the future, e.g. SM I. on Figure 4;

- $\quad$ there are zones, they are well-developed, but they can't be developed well in the future, e.g. SM III. on Figure 4;

- there are zones, they are not well-developed, and they can't be developed well in the future, e.g. Zone I. on Figure 4; 
- there are zones, they are well-developed, and they can be developed well in the future, e.g. Zone III/b on Figure 4.

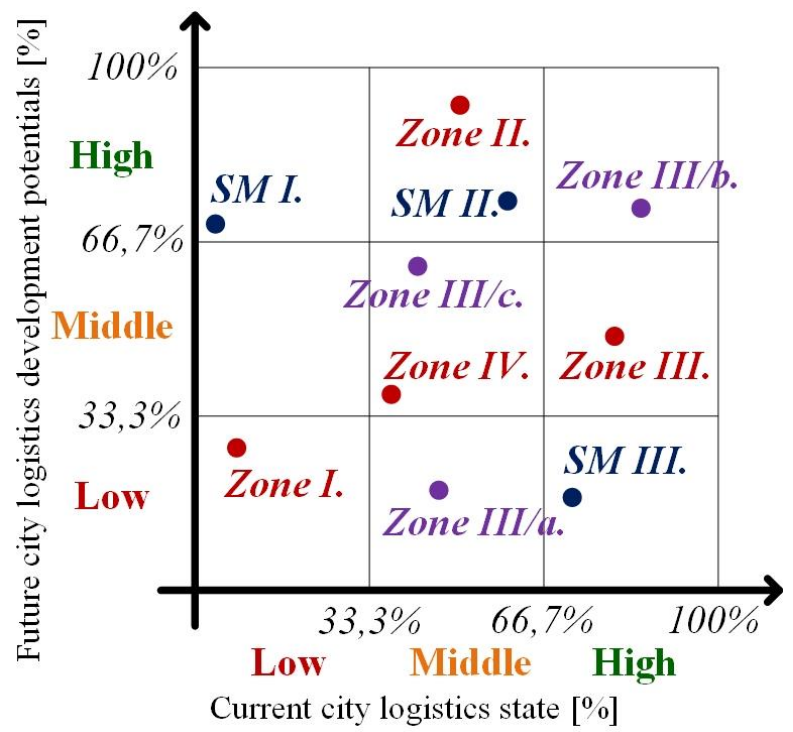

Fig. 4: Example of the results of the two-dimensional AHP-based ranking

In the development process, first we formalized the two-dimensional AHP-based model, then the criteria for both dimensions were defined, and finally, the criteria were ranked by experts of the City Logistics Research Group and by some other experts (Sárdi \& Bóna, 2020/a).

\subsection{AHP-based ranking model}

The first step of the AHP-based ranking is to prepare the comparison matrices for the evaluation of the current state and the development potentials ( $\underline{\underline{A^{P}}}$ and $\underline{\underline{A^{F}}}$ matrices, where $P$ means Present and $F$ means Future). In the matrices, $\bar{A}^{P}{ }_{i}$, and $A^{F}{ }_{k}$ are the examined criteria. The so-defined two comparison matrices can be seen in Table 1 . and in Table 2., where $w^{P}{ }_{i}$ and $w^{F}{ }_{k}$ are the weights of the criteria, $i, j, k$ and $l$ are integer indexes $(i, j=1 \ldots n ; k, l=1 \ldots m)$.

Table 1: The comparison matrix for the evaluation of the current city logistics state

\begin{tabular}{|c|c|c|c|c|c|c|}
\hline & $A_{1}^{P_{1}}$ & $A_{2}^{P_{2}}$ & $\ldots$ & $\boldsymbol{A}_{j}^{\boldsymbol{P}_{j}}$ & $\ldots$ & $A_{n}^{P}$ \\
\hline$A_{1}^{P}$ & $w^{P_{1} / w^{P}{ }_{1}}$ & $w^{P_{1}} / w^{P_{2}}$ & $\ldots$ & $w^{P}{ }^{\prime} / w_{j}{ }_{j}$ & $\ldots$ & $w^{P}{ }_{1} / w^{P_{n}}$ \\
\hline$A^{P_{2}}$ & $w^{P}{ }_{2} / w^{P}{ }_{1}$ & $w^{P}{ }_{2} / w^{P}{ }_{2}$ & $\ldots$ & $w^{P}{ }^{P} / w^{P}{ }_{j}$ & $\ldots$ & $w^{P}{ }^{P} / w^{P}{ }_{n}$ \\
\hline$\ldots$ & $\ldots$ & $\ldots$ & $\ldots$ & $\ldots$ & $\ldots$ & $\ldots$ \\
\hline$\overline{A^{P}{ }_{i}}$ & $w^{P_{i}} / w^{P}{ }_{1}$ & $w^{P}{ }_{i} / w^{P}{ }_{2}$ & $\ldots$ & $w_{i}^{P} / w^{P}{ }_{j}$ & $\ldots$ & $w^{P_{i}} / w^{P}{ }_{n}$ \\
\hline$\ldots$ & & & $\ldots$ & & $\ldots$ & \\
\hline$A_{n}^{P}$ & $w^{P}{ }_{n} / w^{P}{ }_{1}$ & $w^{P}{ }_{n} / w^{P}{ }_{2}$ & $\ldots$ & $w^{P}{ }_{n} / w^{P}{ }_{j}$ & $\ldots$ & $w^{P}{ }_{n} / w^{P}{ }_{n}$ \\
\hline
\end{tabular}


Table 2: The comparison matrix for the evaluation of the future development potentials

\begin{tabular}{|c|c|c|c|c|c|c|}
\hline & $A_{1}^{F_{1}}$ & $A_{2}^{F_{2}}$ & $\ldots$ & $A^{F_{l}}$ & $\ldots$ & $A_{m}^{F}$ \\
\hline$A_{1}^{F_{1}}$ & $w^{F_{1}} / w^{F_{1}}$ & $w^{F_{1}} / w^{F_{2}}$ & $\ldots$ & $w^{F_{l}} / w^{F_{l}}$ & $\ldots$ & $w^{F}{ }_{l} / w^{F}{ }_{m}$ \\
\hline$A^{F_{2}}$ & $w^{F_{2} / w^{F_{1}}}$ & $w^{F_{2} / w^{F}}{ }_{2}$ & $\ldots$ & $w^{F_{2}} / w^{F_{l}}$ & $\ldots$ & $w^{F}{ }_{2} / w^{F}{ }_{m}$ \\
\hline$\ldots$ & $\ldots$ & $\ldots$ & $\ldots$ & $\ldots$ & $\ldots$ & $\ldots$ \\
\hline$A_{k}^{F_{k}}$ & $w_{k}^{F_{k} / w^{F_{1}}}$ & $w_{k}^{F_{k} / w^{F}}$ & $\ldots$ & $w_{k}^{F_{k}} / w^{F_{l}}$ & $\ldots$ & $w^{F}{ }_{k} / w^{F}{ }_{m}$ \\
\hline$\ldots$ & $\ldots$ & & $\ldots$ & ... & $\ldots$ & \\
\hline$A_{m}^{F_{m}}$ & $w^{F}{ }_{m} / w^{F_{l}}$ & $w^{F}{ }_{m} / w^{F_{2}}$ & $\ldots$ & $w^{F_{m}} / w^{F_{l}}$ & & $w_{m}^{F} / w_{m}^{F}$ \\
\hline
\end{tabular}

Based on this, it can be seen that $a^{P}{ }_{i, j}$, and $a^{F}{ }_{k, l}$ items of the matrices (they show us, how more important is criterion " $i$ " than criterion " $j$ ", or criterion " $k$ " than criterion "l", these values will come from the experts' evaluation in this project) can be calculated as in (1) and (2).

$$
\begin{aligned}
& a_{i, j}^{P}=\frac{w_{i}^{P}}{w_{j}^{P}} \\
& a_{k, l}^{F}=\frac{w_{k}^{F}}{w_{l}^{F}}
\end{aligned}
$$

In this case, under and over the main diagonal the values are the reciprocals of each other (as in (3) and (4)).

$$
\begin{aligned}
& a_{i, j}^{P}=\frac{1}{a_{j, i}^{P}} \\
& a_{k, l}^{F}=\frac{1}{a_{l . k}^{F}}
\end{aligned}
$$

The next step of the formalization is to calculate the normalized comparison matrices ( $\underline{\underline{A * P}}$ and $\underline{\underline{A * F}}$ matrices), where first, it is necessary to sum the columns of the comparison matrix and then every item should be divided by this sum, as in (5) and (6). For these new matrices, it is always true, that the sum of the items in one column is 1 .

$$
\begin{aligned}
& a_{i, j}^{* P}=\frac{a_{i, j}^{P}}{\sum_{i=1}^{n} a_{i, j}^{P}} \\
& a_{k, l}^{* F}=\frac{a_{k, l}^{F}}{\sum_{k=1}^{m} a_{k, l}^{F}}
\end{aligned}
$$

Next step is to calculate the weights of the criteria in the AHP model $\left(W_{i}^{P}\right.$ and $\left.W_{k}{ }^{F}\right)$. The main purpose of this is that the sum of the weights must be 1, as in (7) and (8).

$$
\begin{aligned}
& \sum_{i=1}^{n} W_{i}^{P}=1 \\
& \sum_{k=1}^{m} W_{k}^{F}=1
\end{aligned}
$$

We can calculate the weights from the following formula in (9) and (10).

$$
\begin{aligned}
& \left(\underline{\underline{A^{* P}}}-\lambda_{\max }^{P} \times \underline{\underline{E_{n}}}\right) \times \underline{W^{P}}=0 \\
& \left(\underline{\underline{A^{* F}}}-\lambda_{\max }^{F} \times \underline{\underline{E_{m}}}\right) \times \underline{W^{F}}=0
\end{aligned}
$$


where:

- $\lambda_{\max }$ is always the biggest eigenvalue,

- $\quad \underline{\underline{E_{n}}}$ is the $n \times n$ identity matrix,

- $\underline{\underline{E}}_{\underline{\underline{m}}}$ is the $m \times m$ identity matrix,

- $\quad W^{P}$ and $W^{F}$ are the eigenvectors with the weights.

From this system of linear equations, it will be possible to get the $W_{i}^{P}$ and $W_{k}{ }^{F}$ weights.

In the currently examined model, we worked with an estimation method for this, where the weights were calculated as the average of the values in the rows of the matrices, as in (11) and (12).

$$
\begin{aligned}
& W_{i}^{P}=\frac{\sum_{j=1}^{n} a_{i, j}^{* P}}{n} \\
& W_{k}^{F}=\frac{\sum_{l=1}^{m} a_{k, l}^{* F}}{m}
\end{aligned}
$$

Next step of the AHP-based ranking is to check the consistency of the matrices (so the consistency of the comparison of the criteria). For this, first the $P$ values, from multiplying the row vectors of the original matrices $\left(\underline{a}_{i}^{P}\right.$ and $\left.\underline{a}_{k}{ }^{F}\right)$ by the column vectors with the weights $\left(\underline{W^{P}}\right.$ and $\left.\underline{W^{F}}\right)$ and then dividing them by the given weights, as in (13) and (14).

$$
\begin{aligned}
& P_{i}^{P}=\frac{a_{i}^{P} \cdot W^{P}}{W_{i}^{P}} \\
& P_{k}^{F}=\frac{a_{k}^{F} \cdot \frac{W^{F}}{W_{k}^{F}}}{}
\end{aligned}
$$

By use of these values, consistency index $(C I)$ can be calculated, as in (15) and (16).

$$
\begin{gathered}
C I^{P}=\frac{\frac{\sum_{i=1}^{n} P_{i}^{P}}{n}-n}{n-1} \\
C I^{F}=\frac{\frac{\sum_{k=1}^{m} P_{k}^{F}}{m}-m}{m-1}
\end{gathered}
$$

Next step is to give a value to Saaty's random indexes $\left(R I^{P}\right.$ and $\left.R I^{F}\right)$ (Sárdi \& Bóna, 2020/a). In the application of our ranking model, we worked with the interpolation of the Donegan-Dodd experimental results (Sárdi \& Bóna, 2020/a) (Donegan \& Dodd, 1991). Based on the $R I^{P}$ and $R I^{F}$ random indexes, the consistency ratios can be calculated $\left(\mathrm{CR}^{\mathrm{P}}\right.$ and $\left.\mathrm{CR}^{\mathrm{F}}\right)$, as in (17) and (18).

$$
C R^{P}=\frac{C I^{P}}{R I^{P}}
$$




$$
C R^{F}=\frac{C I^{F}}{R I^{F}}
$$

If the $C R$ values are bigger than the experimental 0.1 value, than the examined matrices are consistent. If based on this calculation, the examined matrix is not consistent, it is necessary to make corrections in the comparison matrix.

Next step of the AHP-based ranking is to calculate the preference ratios from the actual values. For this, it was necessary to collect the actual values $\left(T^{P, z}{ }_{i}\right.$ and $\left.T^{F, z}{ }_{k}\right)$ of the given criteria for all examined zones $\left(Z_{1}, Z_{2}, \ldots Z_{w}\right.$, in case of ,w” examined zones; later, in our tests $w=4)$, where ,z" is an integer index $(z=1 \ldots w)$, which belongs to the examined zone. Then, the preference ratios $\left(P_{z, i}{ }^{P}\right.$ and $\left.P_{z, f}{ }^{K}\right)$ can be calculated with this formula (in the default case, the smaller actual values is the bigger; if the bigger value is the better one, it was needed to divide the actual value by the maximum of the actual values), as in (19) and (20).

$$
\begin{aligned}
& P_{z, i}^{P}=W_{i}^{P} \cdot \frac{T_{i, M I N}^{P}}{T_{i}^{P, z}} \\
& P_{z, k}^{F}=W_{k}^{F} \cdot \frac{T_{k, M I N}^{F}}{T_{k}^{F, z}}
\end{aligned}
$$

where:

$$
\begin{array}{ll}
\text { - } & T_{i, M I N}^{P}=\operatorname{MIN}\left\{T_{i}^{P, 1} ; T_{i}^{P, 2} ; \ldots ; T_{i}^{P, w}\right\} \\
\text { - } & T_{k, M I N}^{F}=\operatorname{MIN}\left\{T_{k}^{F, 1} ; T_{k}^{F, 2} ; \ldots ; T_{k}^{F, w}\right\} .
\end{array}
$$

Last step of the ranking is to calculate the ranking values for all examined zones $\left(P_{z}^{P}\right.$ and $\left.P_{z}^{F}\right)$, as in (21) and (22).

$$
\begin{aligned}
& P_{z}^{P}=\sum_{i=1}^{n} P_{z, i}^{P}[\%] \\
& P_{z}^{F}=\sum_{k=1}^{m} P_{z, k}^{F} \quad[\%]
\end{aligned}
$$

These ranking values will provide us the current city logistics state $\left(P_{z}{ }^{P}\right)$ and the future development potential $\left(P_{z}{ }^{F}\right)$ of every examined zone. The bigger the calculated value is, the better is the current state or the development potential of the given zone, the minimum of the values is $0 \%$ and the is $100 \%$ (Sárdi \& Bóna, 2020/a).

\subsection{Criteria of the AHP-based ranking model}

On Figure 5, the purposes of the ranking, the groups of the criteria, the criteria and the examined zones can be seen for a general case. As it is marked on the figure, in case of the current city logistics state, we worked with 43 criteria, and in case of the development potentials with 56 criteria. Four main categories were defined for the criteria (based on their sources and based on our former related research results):

- data from the data collection with our questionnaire;

- $\quad$ simulation-based data; 
- the properties of the logistics and transportation networks, and the related regulations;

- the degree of concentration (we used this category only in case of ranking the future development potentials).

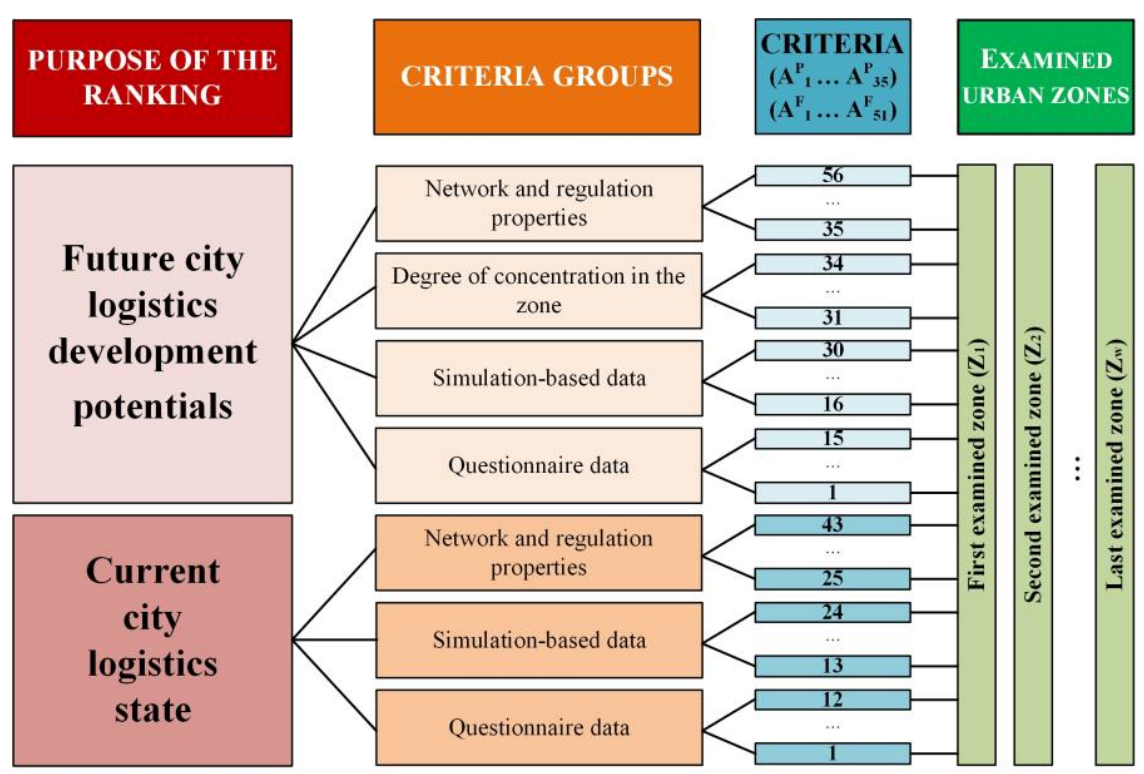

Fig. 5: Decision tree of the AHP-based ranking model

The criteria, which are defined for the evaluation of the current city logistics state, can be seen in the $1^{\text {st }}$ appendix, where some criteria were grouped together, and the numbers will show us, where we are talking about more than one criterion. Additionally, italic letters show those cases, where the bigger value is the better, in every other case, the default situation must be considered, so the smaller values are the better. Where no units are defined, we worked with a scale for the evaluation. The criteria for the evaluation of the future city logistics development potentials can be seen in the $2^{\text {nd }}$ appendix, where the notations are the same as in case of the current state.

In the next step, we decided about the importance of these criteria with experts from the field of city logistics and urban transportation.

\subsection{Criteria evaluation by experts}

For the definition of the importance of the criteria, 18 experts were asked, from the Faculty of Transportation Engineering and Vehicle Engineering the Budapest University of Technology and Economics, from the Clean Air Action Group (Levegő Munkacsoport, 2020) and from the Centre for Budapest Transport (BKK, 2020). In the first round of the evaluation, we received 13 answers, their weights were used in the first tests (where only 35 and 51 criteria were defined in the ranking model). In 
this first round, we received some suggestions from the experts to add new criteria ( 8 for the current state and 5 for the development potentials), so these 18 experts were asked again to weight the new criteria, and we received 11 answers. Based on these answers, the final importance values could be calculated. In the evaluation phase, the experts could choose the 4 categories below, for all criteria: 1 - Less important; 2 Middle important; 3 - Important; or 4 - Very important.

At the decision about the final importance of the criteria, the experience of the experts in the field of city logistics and urban transportation was considered. For this, we categorized the experts in a triple scale. 2 of the experts who answered, belong to the most experienced category (category 3), 4 of them to the middle-experienced category (category 2) and 7 of them to the less experienced category (category 1, mostly students who work for the Research Group). Based on the answers and these categories, we calculated ranking values for the criteria (with considering the maximum sum value of the weights, where every answer is " 4 - Very important"). Based on these values, the criteria were ranked, and based on the shares of the answers, we could decide about the final weights. For example, if the experts chose the " 1 Less important" category in $10 \%$ of all the answers (weighted by their experience), $10 \%$ of all the criteria will belong to this category (in case of 50 examined criteria, the 5 less important criteria). Then, if the " 2 - Middle important" category is chosen in $25 \%$ of all answers, the next $25 \%$ of the ranking will go to this category (so $35 \%$ of all the answers will belong to category 1 and 2), etc. The occurrence of the final categories can be seen on Figure 6 with bold letters, and the data with italic letters shows the occurrence of the answers of the experts.

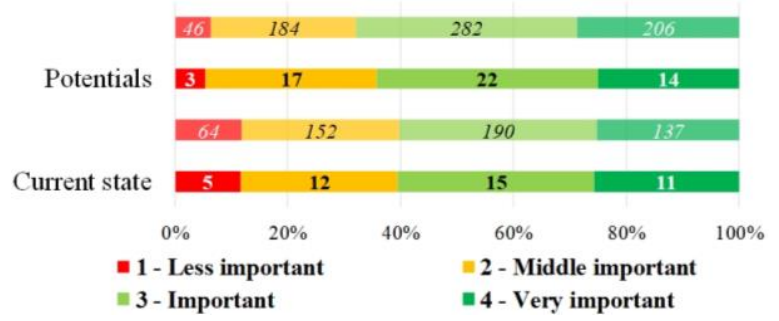

Fig. 6: Occurrence of the categories in the criteria evaluation phase

As it can be seen on Figure 6, the "1 - Less important" category is underrepresented, as the experts chose in most of the cases category $2(28 \%$ in case of the current state, $25.6 \%$ in case of the future potentials), 3 (35\% and 39.3\%) and 4 (25.2\% and $28.7 \%$ ).

\section{Testing the model for shopping malls in Budapest}

From our earlier research phases, we had data and a mesoscopic simulation model for 4 shopping malls from Budapest, so it was decided to test the ranking model on these CSDLs. This means, that in the testing phase, these 4 shopping malls defined the 4 examined zones for us. 


\subsection{The applications' process}

In the testing, the first step was to collect the necessary data for the ranking: we performed analysis on database of the former data collection, we customized our simulation model and performed the simulation runs after experiment design, and we collected all other necessary data from other sources (from the documentation of our researches, e.g. in case of the urban railways or brownfield lands; and from other public databases, e.g. bike path network map or electric charging network databases). These data were added to our ranking model as input data, the comparison matrices were calculated based on the final importance categories of the criteria, then the normalized matrices were calculated, the consistence was checked, and finally, the preference ratios were calculated and the examined zones (shopping malls) were ranked. The full process of the application of the AHP-based multicriterial ranking model can be seen on Figure 7.

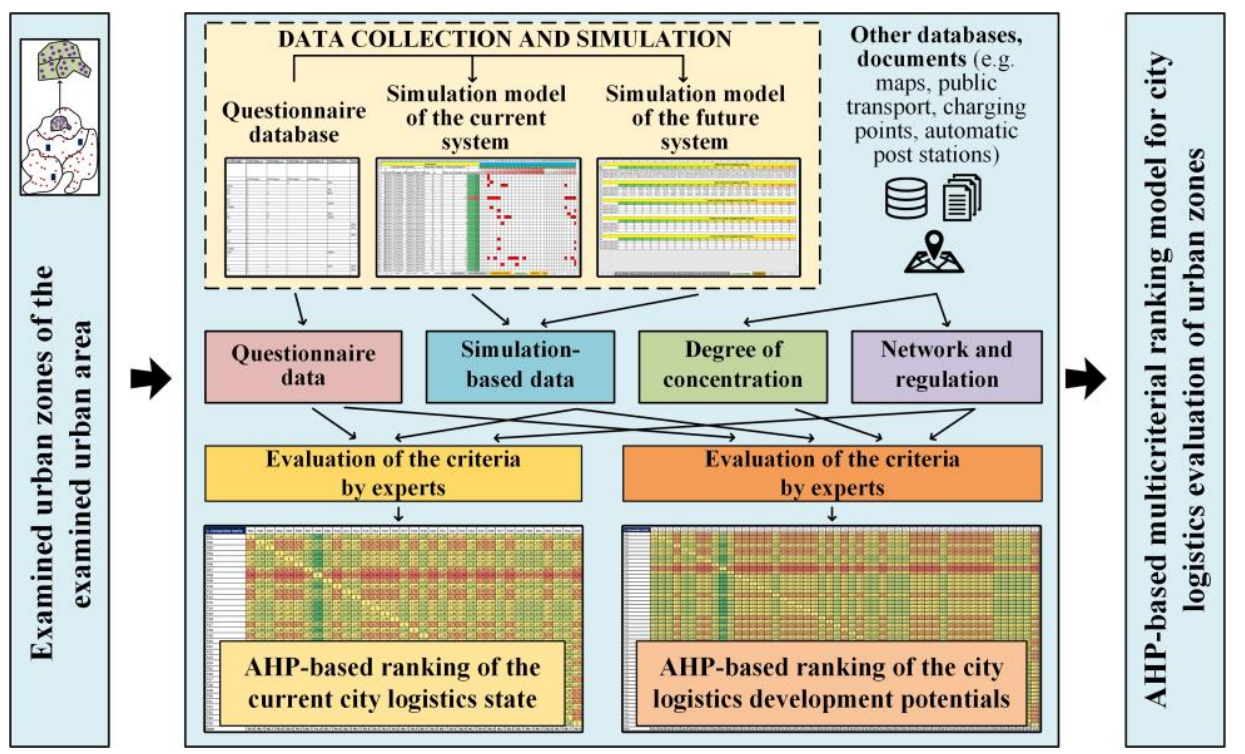

Fig. 7: Application process of the AHP-based ranking model

\subsection{Test without a fictive zone}

First, the tests were performed only for 3 examined shopping malls, with the original criteria (so with the criteria, without the new ones suggested by the experts in the evaluation phase). The results can be seen in Table 3 .

Table 3: Results of the ranking without a fictive zone, for 3 shopping malls

\begin{tabular}{|l|c|c|}
\hline & Current city logistics state & Future city logistics development potentials \\
\hline SM001 & $64,16 \%$ & $82,21 \%$ \\
\hline SM002 & $60,44 \%$ & $71,12 \%$ \\
\hline SM003 & $76,61 \%$ & $69,53 \%$ \\
\hline
\end{tabular}

Based on the results of these tests, the examined zones have a middle or high current city logistics state (with values between $60.4 \%$ and $76.6 \%$ ), and all of them 
have high development potentials (with values between $69.5 \%$ and $82.2 \%$ ). The main problem with these results, that our data collection (Mészáros et. al., 2017) showed earlier, that none of the examined malls is well developed (in the viewpoint of city logistics), several development potentials were discovered, and none of the actual regulations and the actual network is well developed in the zones of the examined shopping malls. Based on these experiences, we can assume, that the middle category would be the correct and real in case of the current state, with values between $50 \%$ and $60 \%$, but in case of the AHP models, the zones are compared only with each other. So, in the currently examined case, the zones can be compared only to the best one of the middle-developed zones, so the final results are distorted upwards. The ranking sequence of the zones will be correct in this case as well, but the final values won't be realistic. As a result of this, we decided to add a so-called fictive zone for the next test.

\subsection{Test with a fictive zone}

We added the fictive zone (in case of these tests basically a fictive shopping mall) to the ranking model, to make it possible to compare the examined zones with a theoretically well-developed zone, with high development potentials. The main properties of the fictive zone were calculated with these approaches:

- $\quad$ in case of values on a scale, the best (the smallest or the biggest) value is chosen;

- in case of percentage values with exact optimum, the best ( $0 \%$ or $100 \%)$ value is chosen;

- in case of other values without an exact optimum (for example the average mileage), that value is chosen, which is $10 \%$ better (smaller or bigger) than the best one of the examined zones (later this value should be optimized as well).

After adding the fictive zone, the AHP-based ranking was performed for 4 zones first, the results of this test can be seen in Table 4, together with the results without a fictive zone (which was already presented in Table III.). It is clear, that adding a fictive zone had a significant effect, and we got more realistic results even for these 3 malls.

Table 4: Results of the ranking for 3 shopping malls, with a fictive zone

\begin{tabular}{|c|c|c|c|c|}
\hline & \multicolumn{2}{|c|}{ Current city logistics state } & \multicolumn{2}{c|}{$\begin{array}{c}\text { Future city logistics development } \\
\text { potentials }\end{array}$} \\
\hline & $\begin{array}{c}\text { Without a fictive } \\
\text { zone }\end{array}$ & $\begin{array}{c}\text { With a fictive } \\
\text { zone }\end{array}$ & $\begin{array}{c}\text { Without a fictive } \\
\text { zone }\end{array}$ & $\begin{array}{c}\text { With a fictive } \\
\text { zone }\end{array}$ \\
\hline SM001 & $64,16 \%$ & $51,41 \%$ & $82,21 \%$ & $70,97 \%$ \\
\hline SM002 & $60,44 \%$ & $48,30 \%$ & $71,12 \%$ & $60,66 \%$ \\
\hline SM003 & $76,61 \%$ & $62,86 \%$ & $69,53 \%$ & $59,25 \%$ \\
\hline $\begin{array}{c}\text { Fictive } \\
\text { zone }\end{array}$ & & $100,00 \%$ & & $100,00 \%$ \\
\hline
\end{tabular}


Next, the fourth shopping mall was added to the tests, and the new criteria (suggested by the experts in the criteria evaluation phase) was added too, so the ranking model was tested for 4 real and for 1 fictive shopping mall in this round, with all criteria of the ranking model. The results can be seen on Figure 8 .

These results are a better reflection of the reality. The fictive zone was the best one in case of every criteria, and the four examined zones are middle developed, with middle development potentials, so the expected results were received after the ranking. The final ranking values can be seen in Table 5., where the colors of the first column are the same as in Figure 8.

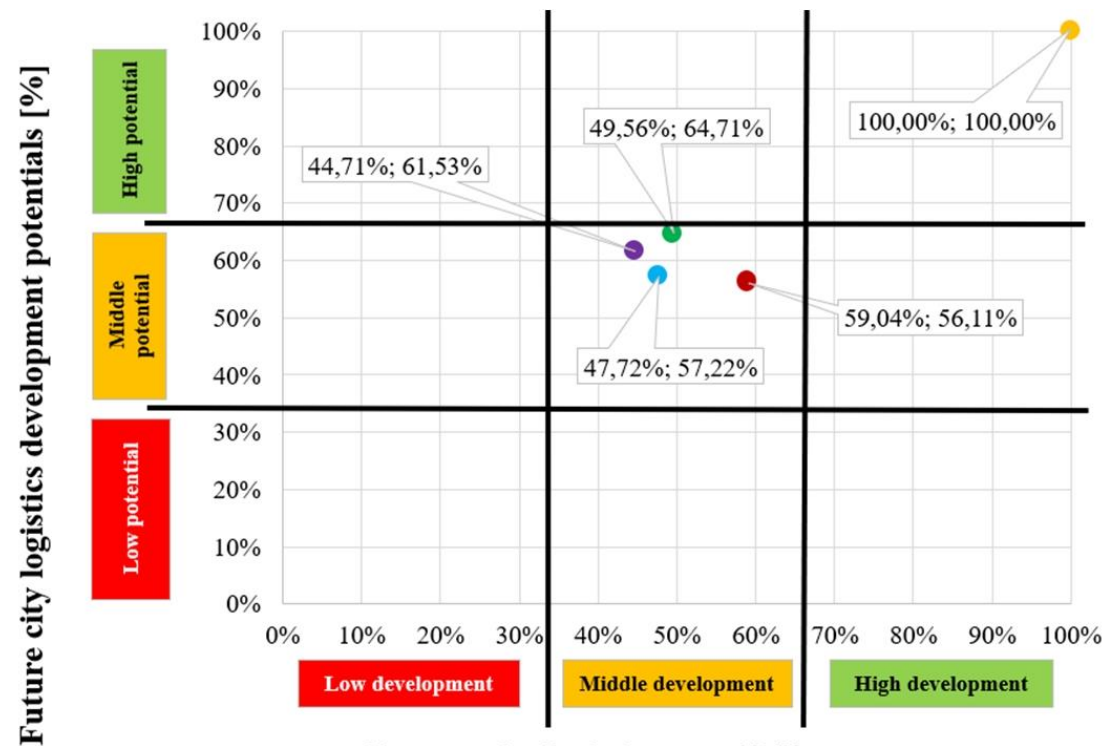

\section{Current city logistics state [\%]}

Fig. 8: Results of the ranking test for 4 shopping malls, with a fictive zone (by orange)

Table 5: Results of the ranking for 4 shopping malls, with a fictive zone

\begin{tabular}{|c|c|c|}
\hline & Current city logistics state & $\begin{array}{c}\text { Future city logistics development } \\
\text { possibilities }\end{array}$ \\
\hline SM001 & $49,56 \%$ & $64,71 \%$ \\
\hline SM002 & $47,72 \%$ & $57,22 \%$ \\
\hline SM003 & $59,04 \%$ & $56,11 \%$ \\
\hline SM004 & $44,71 \%$ & $61,53 \%$ \\
\hline Fictive zone & $100,00 \%$ & $100,00 \%$ \\
\hline
\end{tabular}

Based on these results, it can be said that it will be better to use the solution with a fictive zone in the future, as it gives more realistic results.

As in case of the CSDLs (they were primarily examined in our research earlier, and currently we tested the ranking model on CSDLs) the degree of concentration is a very important indicator, their values were compared with the results of the evaluation of the future development potentials (to get information about possible 
correlation between them and the ranking values), this can be seen in Table 6. (the meaning of $\mathrm{DoC}_{1}$ etc. is defined in the $2^{\text {nd }}$ appendix). Based on the correlation indexes, it is clear, that there is no significant connection and correlation between the development potential and degree of concentration, only in case of the single degree of concentration (with or without considering the multilevel concentrated sets of delivery locations) goes it up to an absolute value of $30-40 \%$.

Table 6: Comparison between the ranking results and the degree of concentration

(DoC) values

\begin{tabular}{|c|c|c|c|c|c|}
\hline & $\mathbf{P}_{\mathbf{z}}^{\mathbf{F}}$ & $\begin{array}{c}\mathbf{D o C}_{\mathbf{1}} \\
{[\text { delivery }} \\
\left.\text { locations } / \mathrm{km}^{2}\right]\end{array}$ & $\begin{array}{c}\mathbf{D o C}_{\mathbf{2}} \\
{[\text { delivery }} \\
\left.\text { locations } / \mathrm{km}^{2}\right]\end{array}$ & $\begin{array}{c}\mathbf{D o C}_{\mathbf{3}} \text { [store } \\
\left.\mathrm{m}^{2} / \mathrm{m}^{2}\right]\end{array}$ & $\begin{array}{c}\mathbf{D o C}_{\mathbf{4}}[\mathrm{store} \\
\left.\mathrm{m}^{2} / \mathrm{m}^{2}\right]\end{array}$ \\
\hline SM001 & $\mathbf{6 4 , 7 \%}$ & 5533,3 & 1383,3 & 1,6 & 0,4 \\
\hline SM002 & $\mathbf{5 7 , 2 \%}$ & 4261,4 & 1153,8 & 2,0 & 0,5 \\
\hline SM003 & $\mathbf{5 6 , 1 \%}$ & 6960,0 & 1871,0 & 1,0 & 0,3 \\
\hline SM004 & $\mathbf{6 1 , 5 \%}$ & 2413,8 & 804,6 & 0,9 & 0,3 \\
\hline Correlation & & $\mathbf{- 3 0 , 6 5 \%}$ & $\mathbf{- 4 0 , 6 8 \%}$ & $\mathbf{0 , 9 3 \%}$ & $\mathbf{1 1 , 7 5 \%}$ \\
\hline
\end{tabular}

\subsection{Sensitivity analysis}

In this phase of the currently examined research project, we already performed some sensitivity analysis, the effects of changing the importance (the weights) of the criteria were analysed, on the results of the ranking, in four different cases:

- in case of constant importance values (all the importance values were the same, there was no difference between the importance of the criteria);

- in case of random importance values with the original share of the four categories;

- in case of random importance values with normal distribution;

- $\quad$ and in case of random importance values with uniform distribution.

In case of the random importance values, 10 different random sets were analysed, and the average results were used for the further analysis. Based on the results of this analysis, it is clear, that changing the importance values won't affect significantly the results:

- in case of the ranking values of the current city logistics state, the average absolute change was $2.7 \%$, with $1.8 \%$ standard deviation (the highest change was $6.0 \%$, the lowest one $0.5 \%$ );

- in case of the ranking values of the future city logistics development potentials, the average absolute change was $0.5 \%$, with $0.3 \%$ standard deviation (the highest change was $1.2 \%$, the lowest one $0.5 \%$ ); 
- in case of the sequence of the current city logistics state, the average absolute change was 0.04 , with 0.05 standard deviation (the highest change was 0.1 , the lowest one 0 );

- and in case of the sequence of the future city logistics development potentials, the average absolute change was 0.08 , with 0.10 standard deviation (the highest change was 0.3 , the lowest one 0 ).

As an example, Figure 9 shows the results of the sensitivity analysis for the current city logistics state.

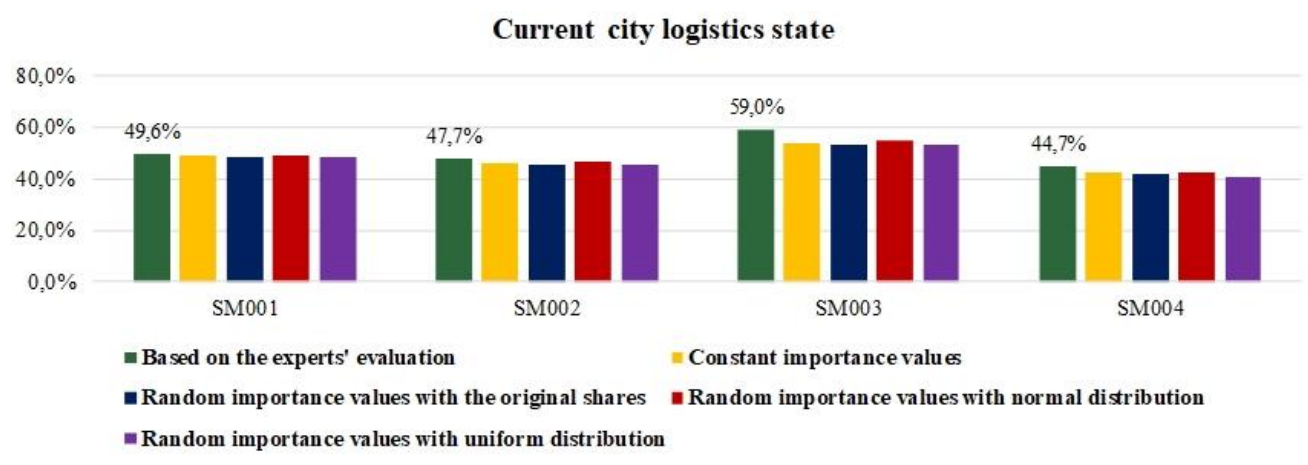

Fig. 9: Results of the sensitivity analysis for the current city logistics state

Next, the next steps of the previously presented research will be defined.

\section{Future Study}

In this project, we developed an AHP-based, two-dimensional ranking model to evaluate the current city logistics state and the future city logistics development potentials of urban zones, it was tested on 4 urban zones defined by 4 shopping malls in Budapest, some sensitivity analysis were also performed, and we already defined the next steps of this research.

First, it is planned to develop a multilevel criteria hierarchy, because of the significant number of criteria in this ranking model. In this multilevel hierarchy, it will be necessary to define the importance of the criteria groups first, and then the importance of the criteria in each group. Next, we would like to implement to the ranking model an algorithm, which makes it possible to calculate the exact, optimal weights, based on the available input data. In the current version of the ranking model, an estimation method was used, presented in (11) and (12). It is also possible, that some new criteria will be added to the ranking model, as at our presentation at the 10th International Conference on Logistics, Informatics and Service Sciences (LISS2020), it was suggested by the audience to add criteria related to the logistics providers in the zone and criteria about the service level in examined zone. From another research project we also got an idea to define the degree of consolidation and 
the potential degree of consolidation in this ranking model. In the next steps, we are going to examine these possible new criteria.

It will be also very important to test the currently examined model on other urban zones as well, as more experience is needed with its use. For this, it is planned to examine the "Váci utca" shopping area from Budapest, because we have data about the delivery locations of this area, its stores were examined by our questionnaire between 2017, March and 2018, August, and a topological model was also developed for the whole area (Sárdi \& Bóna, 2019/b). The first step of this will be to develop the simulation model of this area too. As the examined area is a bigger one with several delivery locations, we plan to work with more subzones. The possible zones of the area can be seen on Figure 10 (4 subzones as an example), but for the exact definition of the subzones, it will be necessary to analyse the topology and the logistics flows as well. Later, we also would like to add the previously examined market with a closed infrastructure to the testing of our ranking model.

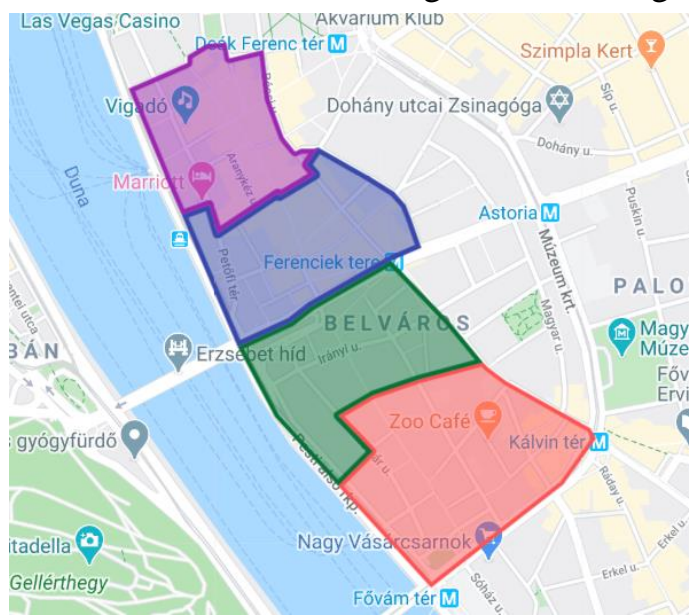

Fig. 10: Possible subzones of the "Váci utca" shopping area in Budapest, on The Google Maps

If the simulation model of the logistics process of the new zones (so the expected 4 subzones of the shopping area and the zone defined by the market) will be ready, we are going to be able to rank 4 shopping malls, 1 market with closed infrastructure and presumably 4 subzones of a shopping area with our AHP-based model. On Figure 11, these 9 zones can be seen with other urban zones from Budapest (with only single delivery locations), these 9 zones will be examined by the ranking model in the next phase of the testing, if the necessary data processing and the simulation will be ready for them. On the figure, the locations of the CSDLs with closed infrastructure are not exact, due to anonymity reasons. 


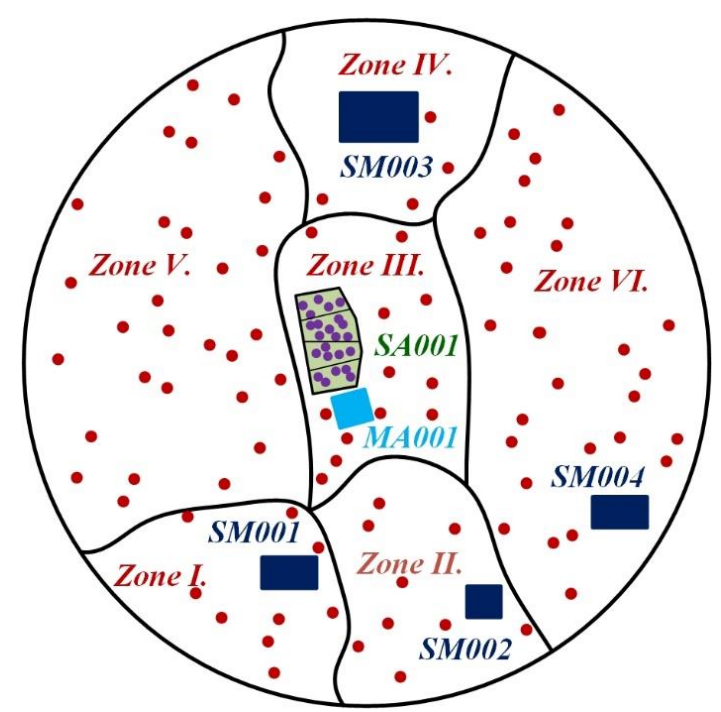

Fig. 11: Model of the examined zones in Budapest

Naturally, as the investigation of the concentrated sets of delivery locations is in the focus of the City Logistics Research Group of our Department, we have data and simulation models about this kind of special delivery locations, these made it possible to test the ranking model. In the future, we would like to add single urban zones with single delivery locations to the model and test it with them too. For this, from some other projects of the University, there is available data, but first, it will be necessary to process them, and it will be also necessary to build simulation models for these areas too.

It will be also a very important task in the future to perform some more sensitivity analysis to examine the effects of changing the actual values for each criterion in our AHP-based ranking model, as the effects of changing the actual values will be able to show, what should be exactly developed, if we would like to increase the city logistics state of the examined zone or we would like to increase the development potentials of the zones.

In a longer term, there are also plans to develop such a tool, which will be able to perform the ranking automatically for any number of zones, if the input files (the actual values of the criteria and results of the experts' evaluation) are available in a standard form. In the current version, we need to customize the ranking file and the input files for the given zones. For this, we plan to use Visual Basic by MS Excel or Python.

\section{Summary}

In this paper, the main purpose was to present an AHP-based, two-dimensional multicriterial ranking model, which makes it possible to evaluate the current city logistics state and the future city logistics development potentials of urban zones. It 
is expected that this ranking model will be able to help future city logistics projects with highlighting those urban zones, they should be developed at all and can be developed well. For choosing the best multicriterial method, a complex literature review was performed and based on that it was decided to use the AHP method, as it is one of the most popular methods in city logistics and other logistics fields. The literature review also showed that the two-dimensional purposes of our project are completely new, there was no ranking model developed for these purposes in city logistics.

In this project, we worked with some former results of our city logistics research, we used the data, which was collected by our own data collection methodology, and we worked with our mesoscopic simulation model too, which helped to examine the current and a gateway-concept based new city logistics system, for urban zones, which were defined by shopping malls, in Budapest. Based on these, four main criteria groups were defined: questionnaire data, simulation-based data, degree of concentration, and regulation and network properties. In this paper, the formalization of the model and the evaluation of the criteria was presented as well. For the evaluation of the importance of the criteria, 18 experts from the field of city logistics and urban transportation were asked. In the first round of evaluation 13 of them answered, then some new criteria were added based on their suggestions and opinion, and in the second round 11 experts answered again about the importance of the new criteria. Based on these answers and based on the level of experience of the experts, the final weights of the criteria were calculated.

By use of these final weights and by use of all other input data, the tests of the multicriterial model for 4 urban zones ( 4 shopping malls) were performed. In the first tests, only these zones were examined, but the results were not appropriate based on the previous data collection from our research, as the AHP compared the middledeveloped zones only with each other, and some of them became well-developed because of this. As a result of this, a so-called fictive zone was added to the ranking, with optimal and good properties, and this helped to get realistic results, the ranking model showed correctly the current state and the development potentials too. We already performed some sensitivity analysis, and based on this we can say, that changing the weights won't significantly affect the results of the ranking. At the end of the paper, some tasks for the next steps of our research were presented too. It will be very important to develop a multilevel criteria hierarchy, to implement the optimal weight calculation and to test the ranking model on more zones to get more experience with its use, but now we can clearly say, that we developed such a multicriterial ranking model, which will be able to rank urban zones in case of future city logistics projects.

\section{Acknowledgements}

The research project between September, 2019 and June, 2020: Supported by the 
ÚNKP-19-3 New National Excellence Program of the Ministry for Innovation and Technology.

The research project after September, 2020: Supported by the ÚNKP-20-3 New National Excellence Program of the Ministry for Innovation and Technology.

\section{References}

Antún, J. \& Alarcón, R. (2014). Ranking Projects of Logistics Platforms: A Methodology Based on the Electre Multicriteria Approach. Procedia - Social and Behavioral Sciences, 160, 5-14.

Awasthi, A. \& Chauhan S. (2011). A hybrid approach integrating Affinity Diagram, AHP and fuzzy TOPSIS for sustainable city logistics planning. Applied Mathematical Modelling, 36, 2, 573-584.

Awasthi, A., Chauhan, S. \& Goyal, S. (2010). A multi-criteria decision making approach for location planning for urban distribution centers under uncertainty. Mathematical and Computer Modelling, 53, 1-2, 98-109.

BKK (2020). BKK in brief. Budapesti Közlekedési Központ. Available: https://bkk.hu/en/main-page/bkk-in-brief/ [Accessed: 2020. 08. 10.]

BME-ALRT (2020). Website of the City Logistics Research Group of the Department of Material Handling and Logistics Systems - A City Logisztikai Kutatócsoport honlapja. Budapest Universityof Technology and Economics. Available: https://www.logisztika.bme.hu/citylog/ [Accessed: 2020. 08. 07.]

Bóna, K. \& Sárdi, D. L. (2018). Analysis and mesoscopic modelling of logistics systems of concentrated urban delivery points - Koncentrált városi igénypontok áruellátó logisztikai rendszereinek elemzése és mezoszkópikus szintü modellezése, Logisztikai Évkönyv 2019, 121-130.

Bóna, K. \& Sárdi, D. L. (2019). New concepts of logistics systems of the urban concentrated sets of delivery points, by use of different transportation modes - A városi koncentrált igénypont-halmazok áruellátási rendszerének új koncepciói a különböző közlekedési alágazatok lehetőségeinek kihasználásával. XIII. IFFK Conference (Innovation and Sustainable Surface Transport), Budapest, 2019.

Bóna, K., Róka, Á. \& Sárdi, D. L. (2018). Mathematical Modelling of the Cost Structure of the Logistics System of Shopping Malls in Budapest. Periodica Polytechnica Transportation Engineering, 46, 3, 142-150. 
Bóna, K., Róka, Á. \& Sárdi, D. L. (2019). Sizing of the cross docks of the urban concentrated sets of delivery points in Budapest - Városi koncentrált igényponthalmazok áruforgalmi zsilipeinek méretezése Budapesten. XIII. IFFK Conference (Innovation and Sustainable Surface Transport), Budapest, 2019.

Donegan H. \& Dodd F. (1991). A note on saaty's random indexes. Mathematical and Computer Modelling, 15, 10, 135-137.

Gogas, M., Adamos G. \& Nathanail E. (2017). Assessing the performance of intermodal city logistics terminals in Thessaloniki. Transportation Research Procedia, 24, 17-24.

Janjevic, M., Knoppen, D. \& Winkenbach, M. (2019). Integrated decision-making framework for urban freight logistics policy-making. Transportation Research Part D: Transport and Environment, 72, 333-357.

Kara, Y. (2019). Measuring the Sustainability of Cities in Turkey with the Analytic Hierarchy Process. Open Journal of Social Sciences, 7, 322-334.

Levegö Munkapcsoport (2020). The Clean Air Action Group. Levegö Munkacsoport. Available: https://www.levego.hu/en/about-us/achievements/ [Accessed: 2020. 08. 10.]

Mészáros, B., Sárdi, D. L. \& Bóna, K. (2016). Developing and testing a methodology for acquiring the logistical characteristics of shopping malls in Budapest, for city logistical solutions. 5th IEEE International Conference on Advanced Logistics and Transport, Krakow, 2016, 154-159.

Mészáros, B., Sárdi, D. L. \& Bóna, K. (2017). Monitoring, measurement and statistical analysis (MMSA) based methodology for improvement city logistics of shopping malls in Budapest. World Review of Intermodal Transportation Research, $6,4,352-371$.

Patier, D. \& Browne, M. (2010). A methodology for the evaluation of urban logistics innovations. Procedia - Social and Behavioral Sciences, 2, 3, 6229-6241.

Saaty, R. (1987). The Analytic Hierarchy Process - What It Is and How It Is Used. Mathematical Modelling, 9, 3-5, 161-176.

Sárdi, D. L. \& Bóna, K. (2017). Developing a mesoscopic simulation model for the examination of shopping mall freight traffic in Budapest. Smart Cities Symposium 2017, Prague. 
Sárdi, D. L. \& Bóna, K. (2018). Macroscopic simulation model of a multi-stage, dynamic cargo bike-based logistics system in the supply of shopping malls in Budapest. Smart Cities Symposium 2018, Prague.

Sárdi, D. L. \& Bóna, K. (2019). Evaluation of the application possibilities of cargo bikes in the logistics system of shopping malls, based on the geometrical structure of the network - Cargo kerékpárok alkalmazási lehetőségeinek értékelése a bevásárlóközpontok logisztikai rendszerében a hálózat geometriai struktúrája alapján. Logisztikai Évkönyv 2020, 163-173.

Sárdi, D. L. \& Bóna, K. (2019). Examination of the logistics systems of concentrated sets of urban delivery points by simulation. The 21th International Conference on Harbor, Maritime \& Multimodal Logistics Modelling and Simulation, Lisbon, 2019, $1-10$.

Sárdi, D. L. \& Bóna, K. (2019). Simulation modelling in the sizing of city logistics systems - a study for concentrated delivery points. International Journal of Engineering and Management Sciences, 4, 1.

Sárdi, D. L. \& Bóna, K. (2020). Developing and application of an AHP-based multicriterial ranking model, for the city logistics analysis of urban areas - AHP alapú multikritériumos minősítési modell kidolgozása és alkalmazása városi övezetek city logisztikai szempontú értékelésére. International Conference on Transport Sciences, Győr, 2020, unpublished.

Sárdi, D. L. \& Bóna, K. (2020). Mesoscopic simulation model of the logistics system of concentrated sets of urban delivery locations. International Journal of Simulation and Process Modelling, under review.

Tadić, S., Zeevi, S. \& Krstić, M. (2014). A novel hybrid MCDM model based on fuzzy DEMATEL, fuzzy ANP and fuzzy VIKOR for city logistics concept selection. Expert Systems with Applications, 41, 8112-8128.

Tadić, S., Zeevi, S. \& Krstić, M. (2017). Sustainability of the city logistics initiatives. 3rd Logistics International Conference (LOGIC 2017), Belgrade, 2017.

Teoh, T., Kunze, O. \& Teo C. (2016). Methodology to Evaluate the Operational Suitability of Electromobility Systems for Urban Logistics Operations. Transportation Research Procedia, 12, 288-300. 
Uysalh, T. \& Kemal, U. (2014). Selection of Logistics Centre Location via ELECTRE Method: A Case Study in Turkey. International Journal of Business and Social Science, 5, 9.

Wątróbski, J., Małecki, K., Kijewska, K., Iwan, S., Karczmarczyk, A. \& Thompson, R. (2017). Multi-Criteria Analysis of Electric Vans for City Logistics. Sustainability, $9,8,1-34$.

Zhao, L., Li, H., Li, M., Sun, Y., Hu, Q., Mao, S., Li, J. \& Xue J. (2018). Location selection of intra-city distribution hubs in the metro-integrated logistics system. Tunnelling and Underground Space Technology, 80, 246-256.

\section{Appendix}

\subsection{Criteria for the evaluation of the current city logistics state}

Questionnaire data:

- $\quad$ 1. Compliance of the actual entry regulations by the delivery locations of the zone [\%]

- 2. Number of different logistics units used by the delivery locations of the zone

- 3. Share of the delivery locations, which use unit loads in the zone [\%]

- 4. Actual share of night deliveries in the zone [\%]

- 5. Actual share of peak time deliveries in the zone [\%]

- 6. Share of delivery location with cargo bike deliveries in the zone [\%]

- 7. Average floor area of the warehouse areas in the examined zone [ $\mathrm{m}^{2} /$ delivery location]

- 8. Average time, which can be served from the full capacity of the delivery locations of the zone [day]

- 9. Share of outbound deliveries in the zone (except the home deliveries) [\%]

- 10. Share of delivery locations with existing IT or ERP system [\%]

- 11. Share of delivery locations with home deliveries in the examined zone $[\%]$

- 12. Share of home deliveries from the delivery locations in the examined zone [\%] (compared to all the goods in the zone)

Simulation-based data:

- 13. Number of arrival delivery transactions to the zone [delivery/time period]

- 14-15. Average mileage and delivery performance of a delivery location in the zone [ $\mathrm{km} /$ location/time period; tkm/location/time period] 
- 16-20. Average $\mathrm{CO}_{2}, \mathrm{CO}, \mathrm{NO}_{x}, \mathrm{HC}$, and $\mathrm{PM}$ of a delivery location in the zone [ $\mathrm{kg} /$ location/time period]

- 21. Average sum stock (in the whole supply system) of an average delivery location in the zone [t/location/time period]

- 22-23. Average sum logistics cost and delivery cost of an average delivery location in the zone [monetary unit/location/time period]

- 24. The sum operation cost of the logistics infrastructure in the zone [monetary unit/time period]

Network and regulation properties:

- 25. The existence of the entry regulations in the examined zone

- 26-27. Adequacy and enforceability of the actual entry regulations in the examined zone

- 28. Verifiability of the actual entry regulation in the examined zone

- 29. Loading possibilities in the examined zone [pcs of loading areas/location]

- 30. Average distance of the delivery locations from the loading areas in the zone $[\mathrm{m}]$

- 31. State of the transportation infrastructure in the examined zone

- 32. Coverage provided by the electric charging network in the examined zone [pcs of chargers $/ \mathrm{km}^{2}$ ]

- 33. Number of package pick points in the zone [pcs]

- 34. Density of the package pick points in the zone [pcs $\left./ \mathrm{km}^{2}\right]$

- 35. Possibilities to include pedestrian couriers

- 36. Possibilities of cargo bike deliveries (availability of proper bike path network)

- 37-39. Share of railway, waterway and combined deliveries in the examined zone [\%]

- 40-41. Share of autonomous delivery vehicles and cargo drones in the examined zone [\%]

- 42-43. Possibilities of deliveries by autonomous delivery vehicles or cargo drones, based on the actual infrastructure and regulations

\subsection{Criteria for the evaluation of the future city logistics development potentials}

Questionnaire data:

- 1. Number of different logistics units used by the delivery locations of the zone [pcs]

- 2. Share of the delivery locations, which use unit loads in the zone [\%]

- 3. Average number of "stock keeping units" (SKUs, goods) of a delivery location in the examined zone [pcs of SKUs] 
- 4. Number of groups of SKUs they can be merged in the examined zone [pcs of SKU groups]

- 5-6. Share of special and perishable/refrigerated goods at an average delivery location in the zone [\%]

- 7. Actual share of night deliveries in the zone [\%]

- 8. Share of delivery location with cargo bike deliveries in the zone [\%]

- 9. Average floor area of the warehouse areas in the examined zone [ $\mathrm{m}^{2} /$ delivery location]

- 10. Average time, which can be served from the full capacity of the delivery locations of the zone [day]

- 11. Share of outbound deliveries in the zone (except the home deliveries) [\%]

- 12. Share of delivery locations with existing IT or ERP system [\%]

- 13-15. Average willingness of the delivery locations to participate in new city logistics systems; average importance of green aspects and average importance of urban transportation aspects for the delivery locations

Simulation-based data:

- 16. Expected reduction of the number of arrival delivery transactions to the zone [\%]

- 17. Sum arrival amount of goods to the examined zone [t/time period]

- 18. Expected reduction of the sum mileage in the examined zone [\%]

- 19. Expected growth of the sum delivery performance in the examined zone [\%]

- 20-24. Expected reduction of the sum $\mathrm{CO}_{2}, \mathrm{CO}, \mathrm{NO}, \mathrm{HC}$, and PM emission in the zone [\%]

- 25. Expected growth of the sum stock (in the whole supply system) of the examined zone [\%]

- 26-27. Expected reduction of the sum logistics cost and delivery cost in the examined zone [\%]

- 28. Expected operation cost of the logistics infrastructure in the examined zone [monetary unit]

- 29-30. Expected investment cost of the cross docks and the common loading areas of the examined zone [monetary unit]

Degree of concentration in the zone:

- 31. Degree of concentration of the examined zone [pcs of delivery locations $/ \mathrm{km}^{2}$ floor area] (in Table VI.: DoC $\mathrm{C}_{1}$ )

- 32. Degree of concentration of the examined zone, with considering the multilevel concentrated sets of delivery locations [pcs of delivery locations $/ \mathrm{km}^{2}$ sum available area] (in Table VI.: DoC $\mathrm{C}_{2}$ ) 
- 33. Area proportional degree of concentration of the examined zone $\left[\mathrm{m}^{2}\right.$ floor area of the delivery locations $/ \mathrm{m}^{2}$ floor area] (in Table VI.: DoC $\mathrm{C}_{3}$ )

- 34. Area proportional degree of concentration of the examined zone, with considering the multilevel concentrated sets of delivery locations $\left[\mathrm{m}^{2}\right.$ floor area of the delivery locations $/ \mathrm{m}^{2}$ sum available area] (in Table VI.: $\mathrm{DoC}_{4}$ )

Network and regulation properties:

- 35. The existence of the entry regulations in the examined zone

- 36-37. Adequacy and enforceability of the actual entry regulations in the examined zone

- 38. Loading possibilities in the examined zone [pcs of loading areas/location]

- 39. Average distance of the delivery locations from the loading areas in the zone $[\mathrm{m}]$

- 40. State of the transportation infrastructure in the examined zone

- 41. Coverage provided by the electric charging network in the examined zone [pcs of chargers $/ \mathrm{km}^{2}$ ]

- 42. Number of package pick points in the zone [pcs]

- 43. Density of the package pick points in the zone $\left[\mathrm{pcs} / \mathrm{km}^{2}\right]$

- 44. Possibilities to include pedestrian couriers

- 45. Possibilities of cargo bike deliveries (availability of proper bike path network)

- 46-47. Possibilities of railway, waterway and combined deliveries in the examined zone

- 49-50. Possibilities of deliveries by autonomous delivery vehicles or cargo drones, based on the actual infrastructure and regulations

- 51-52. Average distance of the delivery locations from the railway and from the waterway network in the examined zone [km]

- 53-54. Number and sum floor area of possible brownfield lands for a cross dock in the examined zone [pcs of possible brownfield lands; $\mathrm{m}^{2}$ floor area of possible brownfield lands]

- 55. Average distance of the loading areas from the possible brownfield lands $[\mathrm{km}]$

- 56. Number of transshipment points in the expected new city logistics system of the examined zone [pcs of transshipment points] 